\title{
Relationship of individual social entrepreneurial orientations and intentions: role of social entrepreneurship education
}

Muhammad Naveed and Muhammad Qamar Zia College of Business Management, Institute of Business Management, Karachi, Pakistan

Sobia Younis

Department of Economics, Hazara University, Mansehra, Pakistan, and

Zubair A. Shah

Department of Management Sciences, Salim Habib University, Karachi, Pakistan

\begin{abstract}
Purpose - The purpose of the study is to probe the influence of individual social entrepreneurship orientations (ISEO) and SE education (SEE) which could affect social entrepreneurial intentions (SEI) among students.

Design/methodology/approach - The data were gathered from 241 entrepreneurship discipline university students. The data were analyzed with structural equation modeling.

Findings - Findings suggest that ISEO plays a vital role in stimulating SEI; moreover, SEE further moderates ISEO and SEI's relationship among students.

Practical implications - Based on the results, academia should focus on SEE and the government should devise policies to encourage social entrepreneurial ventures to aid in social problems solution.

Originality/value - This study validates the relationship of different factors (orientations and intentions) of the theory of planned behavior in the SE domain and confirms the significance of SEE.
\end{abstract}

Keywords Social entrepreneurship education, Social entrepreneurial intention, Individual social entrepreneurial orientations

Paper type Research paper

\section{Introduction}

After the global financial crisis and recession, society started to look for more economically, socially and environmentally sustainable ways of doing business (Hoffman et al., 2012). Among diverse ways of doing business, social entrepreneurship (SE) has played a critical

(C) Muhammad Naveed, Muhammad Qamar Zia, Sobia Younis and Zubair A. Shah. Published in Asia Pacific Journal of Innovation and Entrepreneurship. Published by Emerald Publishing Limited. This article is published under the Creative Commons Attribution (CC BY 4.0) licence. Anyone may reproduce, distribute, translate and create derivative works of this article (for both commercial and non-commercial purposes), subject to full attribution to the original publication and authors. The full terms of this licence may be seen at http://creativecommons.org/licences/by/4.0/legalcode

Role of social entrepreneurship education

Received 27 July 2020 Revised 31 October 2020 Accepted 8 March 2021 
APJIE 15,1

role in developing many developing economies (Hamid et al., 2017). SE is an emerging field of study (Kannampuzha and Hockerts, 2019) and a relatively new phenomenon for dealing with complex social needs. SE is a sub-branch of entrepreneurship (Lortie and Cox, 2018) that endeavors to solve social problems (Hockerts, 2017), obsessed by the sense of commitment and ethical responsibility.

As an entrepreneur, there is a preliminary phase and predictor of entrepreneurship called entrepreneurial intentions (Ajzen, 1991) and referred to as individuals' state of mind to promote entrepreneurial behavior (Hattab, 2014). Similarly, SE is the extension of commercial entrepreneurship, as social entrepreneurial intentions (SEI) are the person's conviction to establish a social enterprise.

For entrepreneurial intentions, there are entrepreneurial personality traits (orientations) that are necessarily anticipated to venture into the entrepreneurial journey (Langkamp Bolton and Lane, 2012). Entrepreneurial orientations are attributes that stimulate entrepreneurial propensities. The concept of entrepreneurial orientation is a bulging theoretical construct in management research and other disciplines (Rauch and Hulsink, 2015). Concerning SE, entrepreneurial orientation has been modified to individual social entrepreneurial orientation (ISEO). It is the person's belief and desire to launch a social enterprise (Tran and Von Korflesch, 2016). Combining the concepts of social responsibility issues and entrepreneurial orientation into SEO has become a new domain in business management (Dwivedi and Weerawardena, 2018) and has scarcely been discussed in the literature.

Entrepreneurship education plays a key role in shaping entrepreneurial orientation and intention among individuals. Entrepreneurship education is used to enhance entrepreneurial aptitude and orientation to promote entrepreneurial intent among university students (Ferreira and Trusko, 2018). SE education (SEE) is emerging as a new area of study in business schools and universities (Choi and Majumdar, 2014). Business universities have started different individual courses and degree programs on SE and offer internship opportunities for students to develop a social enterprise.

Correspondingly, students with SEI are determined by orientations that differentiate entrepreneurs from non-entrepreneurs (Rauch and Frese, 2007). Moreover, higher SEI motivates students to opt for courses related to SE and courses and education programs related to SE, strengthening SE's intention. SEE plays a significant role in developing individuals' entrepreneurial skills and abilities to combine resources effectively and produce innovative solutions to social problems. Furthermore, SEE provides students opportunities for future career decisions to become social entrepreneurs (Smith and Woodworth, 2012).

$\mathrm{SE}$ is highly relevant in developing countries because of peoples' unmet social needs, scarce resources and fewer employment opportunities. In Pakistan, the government and academia are endeavoring to encourage SE. In 2018, the government established "Centre for Social Entrepreneurship" under the Ministry of Planning, Development and Reforms with a mission of supporting students and young entrepreneurs in finding innovative business ideas to solve the pressing problems relevant to the sustainable development goals for people in underprivileged communities through innovation (Ouedraogo and Koff, 2018), whereas in academia, social entrepreneurial education is still in its incubation phase, and only limited business institutes/universities start offering entrepreneurship degree programs and courses.

Research on SE is in the developing phase and scarcely investigated in relation to SEI. Moreover, the determinants of SEI were rarely discussed and limited studies examined the SEI at the individual level (Forster and Grichnik, 2013), and there have been few research efforts made to examine entrepreneurial orientations at the individual level (Sahoo and Panda, 2019). Literature has hardly considered ISEO (innovativeness, pro-activeness, 
risk-taking and social passion), including SEE's relationship and influence in SEI development among students to become social entrepreneurs. The purpose of the study is to fill the gap by probing the relationship between ISEO and SEI with SEE's moderating effect. Despite the benefits of SEE, it is still not as predominant as one would expect. SEE made them understand how to become a social entrepreneur and improve their ability to recognize and leverage knowledge for social venture creation. As a result, SEE provides an opportunity to translate classroom education into the practical shape of a social entrepreneurial venture's start-up. This study intends to make two types of contributions

Role of social entrepreneurship education by filling gaps in the literature of SE by testing the conceptual model: the examination of the relationship between innovativeness, pro-activeness, risk-taking and social passion with SEI and the moderating role of SEE, which could facilitate the development of the social entrepreneurs to help the economy of the country.

\section{Literature review and hypotheses development}

In the literature, the theory of planned behavior (TPB) provides a theoretical framework for intentions to carry out certain behavior shaped by a person's attitude. According to TPB, the intention is an effective and reliable predictor of behavior influenced through attitudinal factors that comprise beliefs about how much an individual intended to perform via certain behavior. Liñán et al. (2011) confirmed that in TPB, an individual's entrepreneurial orientations and intentions are essential variables. Further, entrepreneurial training and education can intensify an individual's entrepreneurial intention. TPB explains the model of SE, as previously its antecedents are unclear and under-researched (Ayob et al., 2013). Subsequently, TPB has rarely investigated SE and its domains, i.e. ISEO and SEI. According to different domains, TPB can be adapted (Krueger et al., 2000). Therefore, the current study aspired to contribute to TPB by validating its social entrepreneurial context assumptions by checking the hypothetical relationships.

\section{Individual social entrepreneurial orientations and social entrepreneurship intentions}

Entrepreneurial orientations are the disposition of a person to be innovative, pro-active and take the risk for an opportunity in the market and predict action for new product development (Covin and Miller, 2014). Mainly entrepreneurial orientations is an important feature of all enterprises and is a firm-level construct, whereas it can also be used at the individual level. Entrepreneurial orientations are adapted to check the individual's intentions to become an entrepreneur rather than check an organization's performance. Individual entrepreneurial orientations (IEO) are psychological factors and highlight the individual's tendency toward entrepreneurship. Moreover, IEO is used to develop business strategy, management and entrepreneurship research.

Besides, IEO is a multi-dimensional construct initially developed by Miller (1983), including innovativeness, pro-activeness and risk-taking. Further, IEO can also be used in the context of SE. Satar and Natasha (2019) developed the scale of ISEO at the individual level, which has four dimensions (innovativeness, pro-activeness, risk-taking and social passion). This study examined the ISEO using four dimensions, risk-taking, pro-activeness, innovations and social passion for checking their individual and combined effects. Risktaking is the tendency of an individual toward engaging in high-risk activities with the chances of high returns in uncertain environments. The individual tends to undertake a certain level of hazard for entrepreneurial action. Additionally, individuals having higher risk-taking propensity have a brighter chance to get involved in entrepreneurship (Hmieleski and Corbett, 2006). Innovativeness is the characteristic of recognizing and responding to opportunities and solutions. It tends to engage in creative processes, with the 
APJIE 15,1

induction of new products and services (Rauch et al., 2009). The next dimension is proactiveness, referring to entrepreneurial behavior to create new opportunities to shape the future environment (Lumpkin and Dess, 2001). The opportunity-seeking behavior incorporates acting on future needs and trends ahead of competitors to develop new products and craft first-mover advantages (Anderson et al., 2015). The last of the four characteristics, social passion, manifests the social entrepreneur's commitment to minimize others' problems and is enthusiastic about positive social value creation.

Entrepreneurial intention is the conviction based on one's capabilities and readiness to establish an enterprise and is best defined as a "self-acknowledged conviction by a person that they intend to set up a new business venture and consciously plan to do so at some point in the future" (Thompson, 2009). In SE, SEI is considered an extension of commercial entrepreneurship and a person's desire to launch a social enterprise. Literature has shown a theoretical and empirical association between IEO and entrepreneurial intention (Covin et al., 2006). Contrary to commercial entrepreneurship, SE is an action with social embeddedness. By merging social with EO's concepts becomes SEO and emerge as a new concept in business management. The "social" aspect of SE relates to helping others; while changing the context from commercial entrepreneurship to SE, the level of orientations and intentions will also be changed from entrepreneurial orientations and intentions to SEO intentions for running the business in the future. Hence, this reasoning develops the following hypothesis:
H1. ISEO (a) innovativeness, positively influences SEI.
(b) risk-taking,
(c) pro-activeness,
(d) social passion positively influences SEl.

\section{Social entrepreneurship education, individual social entrepreneurial intentions and social entrepreneurship intentions}

Education is a way to provides basic knowledge and skills about any concept, including entrepreneurship, and it is considered an important factor for the understanding of the entrepreneurship process (Fayolle and Gailly, 2015). Entrepreneurial education has gained tremendous attention from universities, policymakers and entrepreneur researchers. Existing studies of numerous different countries demonstrated a positive relationship between education and SE (Martín and Cuervo-Arango, 2016). Entrepreneurship education influence on IEO of students, which, in turn, affects their intentions to adopt an entrepreneurial career and becoming self-employed.

The entrepreneurship education is based on strengthening the participant's intention to become an entrepreneur. Education related to the entrepreneurship concept is considered an important factor in developing entrepreneurial skills and competencies such as innovativeness, risk-taking and pro-activeness called entrepreneurial orientations among university students. Earlier studies identified that entrepreneurial education played a significant role and profoundly impacted IEO and increased entrepreneurial intentions. People with training and education about entrepreneurship programs have a higher aptitude toward IEO. Entrepreneurial education also impacts the antecedent of entrepreneurial orientations, such as risk-taking and pro-activeness of students. Entrepreneurship education is a critical and influential factor for developing entrepreneurial intentions through individual attitudes and cognition, which leads to entrepreneurial behavior. SEE helps students build self-efficacy in students by modeling the learning process and using persuasion, thus providing them with mastery in experiences. In the previous research, entrepreneurship education was found directly and moderately related to 
entrepreneurial intentions and positively impacted university students (Lorz and Volery, 2011). Based on the discussion mentioned above, it has been hypothesized as follows:

H2. SEE moderate the relationship of ISEO (a) innovativeness, (b) risk-taking, (c) proentrepreneurship activeness, (d) social passion and SEI.

This study adopted a positivist approach and quantitative research design by using a survey questionnaire. The selected sample comprises graduate and postgraduate students from six different private and public sector universities in Pakistan. The student studied entrepreneurship and had completed a SE course as an elective or enrolled in the entrepreneurship degree program, and the students in the process of going through a SE internship program.

Data were collected through online google doc and by visiting classes of the SE department. Firstly, the study purpose has been explained and then asked to participate voluntarily in the survey; questionnaires were distributed among students to collect their responses. A convenience method of sampling was used for the data collection. The item was measured on a five-point Likert scale with $1=$ strongly disagree to $5=$ strongly agree, and the questionnaire was developed by adapting existing empirically tested measurements of each latent construct. There were 280 questionnaires distributed to the students online and hard copies. The overall response rate was high; 252 responses were received, out of which 11 were dropped due to outliers and multivariate normality issues. Outliers and multivariate normality were checked through Mahalanobis $\left(d^{2}\right)$ square distance values. Overall useable surveys were 241 with an $86 \%$ response rate which meets the minimum sample size required for structural equation modeling. The minimum sample size required is 230 as the questionnaire has 23 items. Table 1 summarizes the demographic details.

\section{Measures}

ISEO was measured by using the scale developed by Satar and Natasha (2019). One sample item is "I tend to act boldly in situations where risk is involved." Overall, ISEO consists of 14 items $($ risk-taking $=03$; innovativeness $=04$; pro-activeness $=03$, social passion $=04$ ).

\begin{tabular}{|c|c|c|c|}
\hline Variable & $n$ & $(\%)$ & \\
\hline \multicolumn{4}{|l|}{ Gender } \\
\hline Male & 160 & 66.4 & \\
\hline Female & 81 & 33.6 & \\
\hline \multicolumn{4}{|l|}{ Age Group } \\
\hline Less than 25 & 106 & 44.0 & \\
\hline $25-32$ & 68 & 28.2 & \\
\hline $33-40$ & 61 & 25.3 & \\
\hline Above 40 & 6 & 2.5 & \\
\hline \multicolumn{4}{|l|}{ Qualification } \\
\hline Graduation & 75 & 31.1 & \\
\hline Masters & 153 & 63.5 & \\
\hline MS/MPhil/PHD & 13 & 5.4 & Table 1 \\
\hline Total & 241 & 100 & Demographics \\
\hline
\end{tabular}


APJIE

15,1

44

SEI was measured by using the scale developed by Hockerts (2017). A sample item is "I have a preliminary idea for a social enterprise on which I plan to act in the future." The SEI consists of 03 items.

The SEE questionnaire was adapted from a questionnaire of entrepreneurship education developed by Lorz and Volery (2011) and consists of items. A sample item is "To what extent do you value your depth of knowledge in the following areas of social entrepreneurship?"

\section{Results}

The data were analyzed with structural equation modeling using SPSS and AMOS. The measurement model includes composite reliability (CR), average variance extracted (AVE) and confirmatory factor analysis (CFA). Model fit was tested through "chi-square $\left(\chi^{2}\right)$ : goodness-of-fit index (GFI > 0.90); comparative fit index (CFI > 0.90); Tucker-Lewis Index (TLI > 0.90); root mean square error of approximation (RMSEA $>0.08$ ) and standardized root mean square (SRMR $>0.06$ )." The structural model includes testing of hypothesis. Descriptive statistics such as means, standard deviations and correlations of study variables are presented in Table 2 . The study variables' correlations range from 0.26 to 0.57 and show no possibility of multicollinearity.

\section{Investigating the measurement model}

A reliability check was carried out for each of the latent variables. Factor analyses, tests for discriminant validity, construct validity and reliability tests and model fit were all performed. Table 2 presents Cronbach's alpha values, and CR is at an acceptable level of each latent variable, which is $a>0.70$. Further, to access convergent validity, AVE and composite reliabilities were checked. In the model, all latent constructs $\mathrm{CR}$ ranges from 0.77 to 0.90 , and the AVE value is greater than 0.50 . Thus, all the measures of this study confirm convergent validity.

Discriminant validity is used to explain the uniqueness of each latent variable. In Table 2, correlation values of study variables range from 0.26 to 0.57 , and the square root of AVE (in bold) are mentioned, and values are higher than the correlation of each item, and thus, discriminant validity of all constructs was established (Table 3).

\begin{tabular}{lrrrccccc}
\hline Construct & 1 & \multicolumn{1}{c}{2} & \multicolumn{1}{c}{3} & 4 & 5 & 6 & 7 & 8 \\
\hline 1.Age & & & & & & & & \\
2.Gender & 0.05 & & & & & & & \\
3.Education & 0.12 & -0.02 & 1.00 & & & & & \\
4.Innovativeness & 0.06 & -0.02 & 0.02 & 0.73 & & & & \\
5.Risk taking & -0.01 & -0.02 & 0.02 & $0.32^{* *}$ & 0.73 & & & \\
6 Pro-activeness & -0.05 & 0.00 & 0.04 & $0.52^{* *}$ & $0.30^{* *}$ & 0.74 & & \\
7.Social passion & -0.07 & -0.08 & -0.06 & $0.24^{* *}$ & $0.33^{* *}$ & $0.29^{* *}$ & 0.76 & \\
8.SEE & -0.08 & 0.04 & 0.06 & $0.26^{* *}$ & $0.29^{* *}$ & $0.30^{* *}$ & $0.30^{* * *}$ & 0.78 \\
9.SEI & -0.06 & -0.05 & 0.00 & $0.42^{* *}$ & $0.39^{* *}$ & $0.45^{* *}$ & $0.57^{* *}$ & $0.36^{* *}$ \\
Mean & 2.03 & 1.34 & 1.87 & 3.46 & 3.53 & 3.55 & 3.49 & 3.48 \\
Std Dev & 1.11 & 0.47 & 0.63 & 0.73 & 0.72 & 0.70 & 0.74 & 0.65 \\
& & & & & & & &
\end{tabular}

Table 2 .

Correlation, descriptive statistics and discriminant validity
Notes: SEE $=$ Social entrepreneur education, SEI $=$ Social entrepreneur intention: $* p<0.05 ; * * p<0.01$; square root of average variance extracted (AVE) is italic 


\begin{tabular}{|c|c|c|c|c|c|c|}
\hline Construct & Indicator & Std L & $\alpha$ & $\mathrm{CR}$ & AVE & $\begin{array}{l}\text { Role of social } \\
\text { entrepreneurship }\end{array}$ \\
\hline Innovativeness & $\begin{array}{l}\text { INNO1 } \\
\text { INNO2 } \\
\text { INNO3 } \\
\text { INNO4 }\end{array}$ & $\begin{array}{l}0.728 \\
0.742 \\
0.754 \\
0.689\end{array}$ & 0.831 & 0.819 & 0.531 & education \\
\hline Risk-taking & $\begin{array}{l}\text { RT1 } \\
\text { RT2 } \\
\text { RT3 }\end{array}$ & $\begin{array}{l}0.714 \\
0.765 \\
0.708\end{array}$ & 0.772 & 0.773 & 0.532 & 45 \\
\hline Pro-activeness & $\begin{array}{l}\text { PROA1 } \\
\text { PROA2 } \\
\text { PROA3 }\end{array}$ & $\begin{array}{l}0.686 \\
0.833 \\
0.688\end{array}$ & 0.772 & 0.781 & 0.546 & \\
\hline Social passion & $\begin{array}{l}\text { SP1 } \\
\text { SP2 } \\
\text { SP3 } \\
\text { SP4 }\end{array}$ & $\begin{array}{l}0.735 \\
0.782 \\
0.77 \\
0.767\end{array}$ & 0.850 & 0.848 & 0.583 & \\
\hline Social entrepreneur education & $\begin{array}{l}\text { SEE1 } \\
\text { SEE2 } \\
\text { SEE3 } \\
\text { SEE4 } \\
\text { SEE5 } \\
\text { SEE6 }\end{array}$ & $\begin{array}{l}0.747 \\
0.753 \\
0.750 \\
0.792 \\
0.778 \\
0.811\end{array}$ & 0.911 & 0.899 & 0.596 & \\
\hline Social entrepreneur intention & $\begin{array}{l}\text { SEI1 } \\
\text { SEI2 } \\
\text { SEI3 }\end{array}$ & $\begin{array}{l}0.721 \\
0.798 \\
0.723\end{array}$ & 0.788 & 0.792 & 0.560 & $\begin{array}{r}\text { Table 3. } \\
\text { Factor loading, }\end{array}$ \\
\hline \multicolumn{6}{|c|}{$\begin{array}{l}\text { Notes: } \mathrm{Std} \mathrm{L}=\text { Standard loading, } \alpha=\text { Cronbach's alpha, } \mathrm{CR}=\text { Composite reliability, } \mathrm{AVE}=\text { Average } \\
\text { variance extracted }\end{array}$} & $\begin{array}{r}\text { reliability and } \\
\text { validity }\end{array}$ \\
\hline
\end{tabular}

Furthermore, CFA was also used for the estimation of the measurement model. The four dimensions of social entrepreneur orientations along with social entrepreneur education and intentions were plotted in AMOS 24.0 simultaneously, which yielded the best fit $\left(X^{2} / d f=1.475, \mathrm{CFI}=0.96, \mathrm{GFI}=0.90, \mathrm{TLI}=0.95, \mathrm{SRMR}=0.048\right.$ and $\left.\mathrm{RMSEA}=0.044\right)$.

\section{Hypotheses testing}

Direct effect. The results of direct effect presented in Table 4 and hypothesized model of main effect also showed a good fit $\left(\chi^{2} / d f=1.41, \mathrm{CFI}=0.97, \mathrm{GFI}=0.94, \mathrm{TLI}=0.97, \mathrm{SRMR}=\right.$ 0.044 and RMSEA $=0.041)$. Table 4 shows that innovativeness $(\beta=0.20, p<0.05)$, risk taking $(\beta=0.15, p<0.05)$, Pro-activeness $(\beta=0.20, p<0.05)$ and social passion $(\beta=0.45$, $p<0.001$ ) has direct and positive effect on students SEI providing support for $H 1 a, H 1 b$, $H 1 c$ and $H 1 d$. The squared multiple correlations $\left(R^{2}\right)$ is used to determine the potency of

\begin{tabular}{lccccc}
\hline Hypothesis & Path Coeff & StdErr & CR. & $p$-value & Result \\
\hline H1a. Innovativeness $\rightarrow$ SEI & 0.196 & 0.061 & 3.21 & 0.001 & Accepted \\
H1b. Risk-taking $\rightarrow$ SEI & 0.154 & 0.058 & 2.67 & 0.008 & Accepted \\
H1 . Pro-activeness $\rightarrow$ SEI & 0.200 & 0.065 & 3.09 & 0.002 & Accepted \\
H1d. Social Passion $\rightarrow$ SEI & 0.450 & 0.056 & 8.11 & 0.000 & Accepted
\end{tabular}

Note: $\mathrm{SEI}=$ Social entrepreneur intention

Table 4.

Direct effect results 
APJIE

15,1

46

model. Figure 1 presents that the value of $R^{2}$ is 0.45 which states that $45 \%$ variance is explained by the model.

Examining the interaction effect. The interaction effect of SEE was examined between the relationship of SEOs' dimensions and SEI. The values of variables were regressed, and all three variables (dependent, moderator and dependent $\times$ moderator) were taken as a predictor of the independent variable. Table 5 shows that interaction term of SEE and innovativeness $(\beta=0.128, p<0.05)$, risk-taking $(\beta=0.133, p<0.05)$, pro-activeness ( $\beta=0.193, p<0.001$ ) significantly and positively related to SEI supporting $H 2 a, H 2 b$ and $H 2 c$. The association between the interaction term of SEE and social passion with SEI was not significant $(\beta=0.193, p<0.001$ ), contrary to $H 3 d$. The plotted presentation of the interaction effect is displayed in Figure 2.

\section{Discussion}

The study endeavored to fill the gap by checking SEI predicted through innovativeness, risk-taking, pro-activeness, social passion and relevant education among students of

Figure 1.

Study model

\section{Table 5.}

Summary of interaction effect on social entrepreneur intention

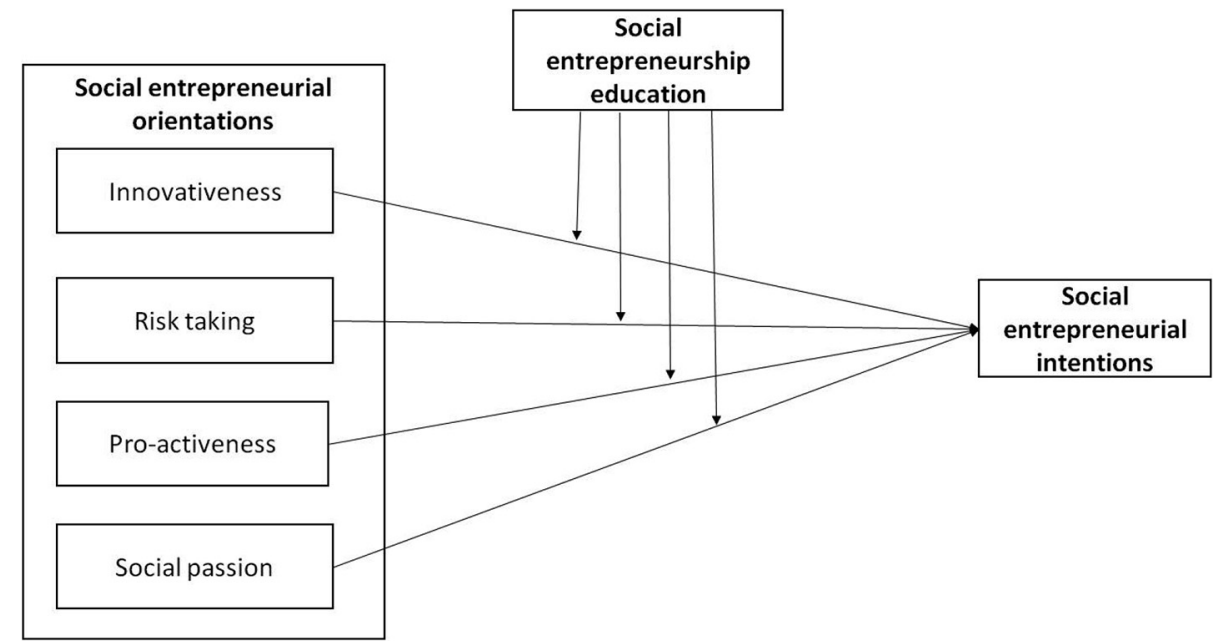

\begin{tabular}{|c|c|c|c|c|c|c|}
\hline Hypothesis & Structural relationship & St. estimates $(\beta)$ & $\mathrm{CR}$ & $p$-value & $R^{2}$ & Result \\
\hline \multirow[t]{3}{*}{$H 2 a$} & $\mathrm{SEI} \leftarrow \mathrm{INNO}$ & 0.354 & 6.17 & 0.000 & \multirow{3}{*}{0.26} & \multirow[t]{3}{*}{ Accepted } \\
\hline & $\mathrm{SEI} \leftarrow \mathrm{SEE}$ & 0.253 & 4.39 & 0.000 & & \\
\hline & $\mathrm{SEI} \leftarrow \mathrm{INNO} \times \mathrm{SEE}$ & 0.128 & 2.35 & 0.018 & & \\
\hline \multirow[t]{3}{*}{$H 2 b$} & $\mathrm{SEI} \leftarrow \mathrm{RT}$ & 0.313 & 5.33 & 0.000 & \multirow{3}{*}{0.24} & Accepted \\
\hline & $\mathrm{SEI} \leftarrow \mathrm{SEE}$ & 0.269 & 4.58 & 0.000 & & \\
\hline & $\mathrm{SEI} \leftarrow \mathrm{RT} \times \mathrm{SEE}$ & 0.133 & 2.62 & 0.009 & & \\
\hline \multirow[t]{3}{*}{$H 2 c$} & $\mathrm{SEI} \leftarrow \mathrm{PRO}$ & 0.348 & 6.10 & 0.000 & \multirow{3}{*}{0.30} & Accepted \\
\hline & $\mathrm{SEI} \leftarrow \mathrm{SEE}$ & 0.214 & 3.72 & 0.000 & & \\
\hline & $\mathrm{SEI} \leftarrow \mathrm{PRO} \times \mathrm{SEE}$ & 0.193 & 3.80 & 0.000 & & \\
\hline \multirow[t]{3}{*}{$H 2 d$} & $\mathrm{SEI} \leftarrow \mathrm{SP}$ & 0.494 & 9.13 & 0.000 & \multirow{3}{*}{0.37} & Rejected \\
\hline & $\mathrm{SEI} \leftarrow \mathrm{SEE}$ & 0.187 & 3.42 & 0.000 & & \\
\hline & $\mathrm{SEI} \leftarrow \mathrm{SP} \times \mathrm{SEE}$ & 0.092 & 1.89 & 0.058 & & \\
\hline
\end{tabular}




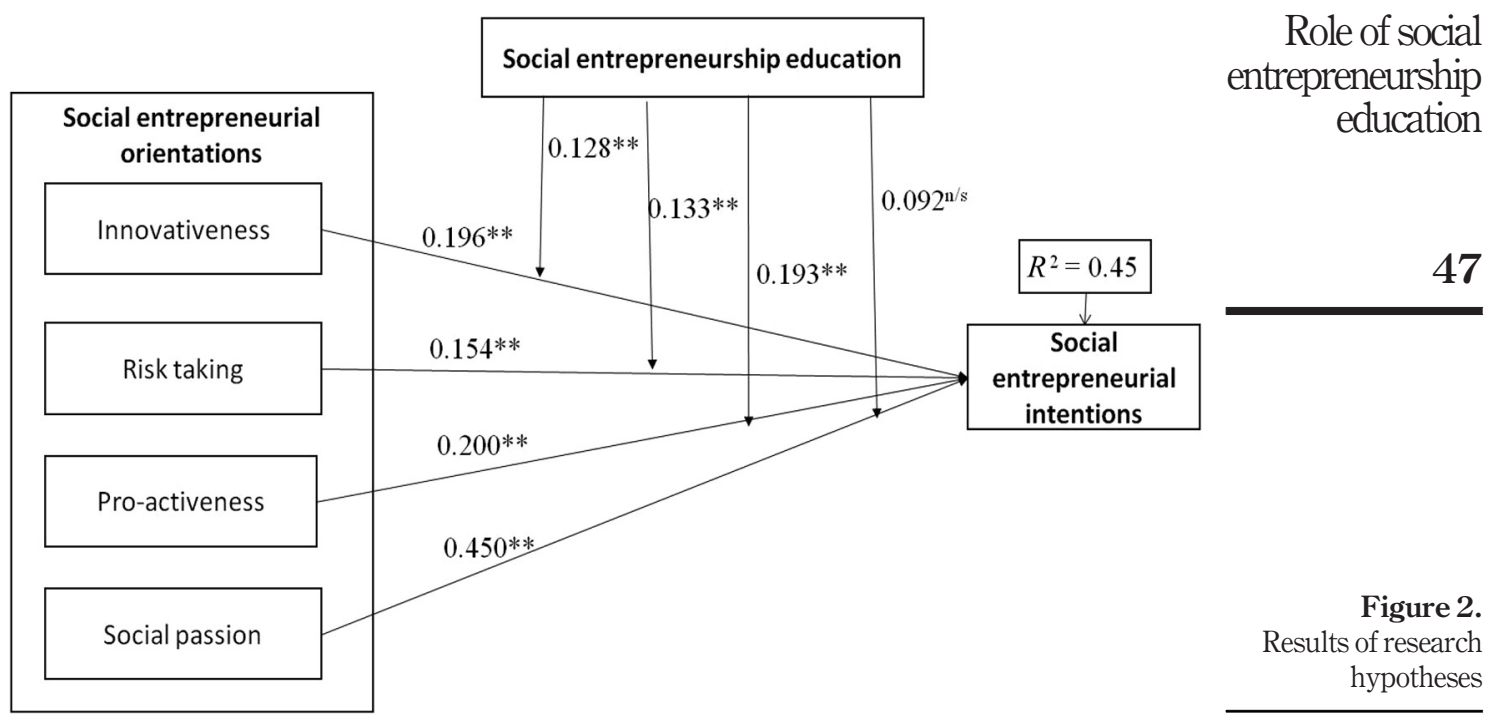

entrepreneurship. First, the direct relationship between ISEO (innovativeness, risk-taking, pro-activeness and social passion) and SEI is supported according to the authors' supposition. The results state that innovativeness, risk-taking, pro-activeness and social passion significantly increases SEI among the students. A possible explanation is that such students would be behaviorally aligned to perform a certain action and concerned with social issues have higher intentions to become a social entrepreneur. The findings are consistent with the prior entrepreneurship studies.

Furthermore, the second assumption of the study regarded SEE's moderating role between the relationship between ISEO's dimensions (innovativeness, risk-taking, pro-activeness and social passion) and SEI. The results show that SEE moderates positively and significantly between ISEO and SEI. However, the moderating effect of social passion was statistically insignificant with a positive direction. The existence of the moderation effect of overall SEE is consistent in past studies which analyzed the effect of entrepreneurial education. Resultantly, it has proved that SEE increases the students' intentions who are oriented to become social entrepreneurs.

Conclusively, this paper provided significant empirical contribution and argued that SEE provides a way forward to prepare a community of social entrepreneurs, further enhancing the concept of SE.

\section{Conclusion}

The current study provides a new direction in terms of a less explored area of SE. In this study, we have explored the influence of ISEO on SEI and SEE's role among entrepreneurship students who were enrolled in the SE discipline or have successfully passed an elective course of SE.

In the literature of SE, the current study contributes to how SEE provides empirical proof to act as a moderating variable on the relationship between ISEO and SEI of the students. This research concludes that students with SEE will consider SE a preferred means to enhance their careers. SE provides a critical path to economic and social development, and the current study underscores important implications for academicians and policymakers. 
APJIE 15,1

SE has the potential to create a positive impact on the economy and society. Therefore, the government and private sector should acknowledge the importance of SE and take appropriate steps to encourage SE as a cause. In light of the prevailing situation of developing countries (huge population, poverty and unemployment), the government solely would not be able to cater to all problems. SEE indoctrinated in students to get mastery to commercialize their social capabilities. Overall, SEE could facilitate by reducing unemployment to help the overall economy of the country.

Based on findings, the current study made contributions in SE though it has certain limitations. The current study exclusively focused on the students' intentions; future studies could also focus on employees of different SE organizations to check their intrinsic motivation (El-Zohiry and Abd-Elbaqy, 2019). There may also be other factors yet to be discovered for which further research is needed. Moreover, to rectify statistical deficiency, data could also be collected from other sources with similar variables.

\section{References}

Ajzen, I. (1991), "The theory of planned behavior", Organizational Behavior and Human Decision Processes, Vol. 50 No. 2, pp. 179-211.

Anderson, B.S., Kreiser, P.M., Kuratko, D.F., Hornsby, J.S. and Eshima, Y. (2015), "Reconceptualizing entrepreneurial orientation", Strategic Management Journal, Vol. 36 No. 10, pp. 1579-1596.

Ayob, N., Yap, C.S., Sapuan, D.A. and Rashidd, Z.A. (2013), "Social entrepreneurial intention among business undergraduates: an emerging economy perspective", Gadjah Mada International Journal of Business, Vol. 15 No. 3, pp. 249-267.

Choi, N. and Majumdar, S. (2014), "Social entrepreneurship as an essentially contested concept: opening a new avenue for systematic future research", Journal of Business Venturing, Vol. 29 No. 3, pp. 363-376.

Covin, J.G. and Miller, D. (2014), "International entrepreneurial orientation: conceptual considerations, research themes, measurement issues, and future research directions", Entrepreneurship Theory and Practice, Vol. 38 No. 1, pp. 11-44.

Covin, J.G., Green, K.M. and Slevin, D.P. (2006), "Strategic process effects on the entrepreneurial orientation - sales growth rate relationship", Entrepreneurship Theory and Practice, Vol. 30 No. 1, pp. 57-81.

Dwivedi, A. and Weerawardena, J. (2018), "Conceptualizing and operationalizing the social entrepreneurship construct", Journal of Business Research, Vol. 86, pp. 32-40.

El-Zohiry, A.A. and Abd-Elbaqy, K.Y. (2019), "The moderating effect of intrinsic motivation on the relationship between psychological capital and organizational citizenship behaviors", Management Review: An International Journal, Vol. 14 No. 2, pp. 4-32.

Fayolle, A. and Gailly, B. (2015), "The impact of entrepreneurship education on entrepreneurial attitudes and intention: hysteresis and persistence", Journal of Small Business Management, Vol. 53 No. 1, pp. 75-93.

Ferreira, J.J. and Trusko, B.E. (2018), "Guest editorial: innovation and entrepreneurship in the HEI sector", International Journal of Innovation Science, Vol. 10 No. 1, pp. 2-5.

Forster, F. and Grichnik, D. (2013), "Social entrepreneurial intention formation of corporate volunteers", Journal of Social Entrepreneurship, Vol. 4 No. 2, pp. 153-181.

Hamid, Z., Hengchao, Z. and Mhd-Sarif, S. (2017), "Economic theories of social entrepreneurship", International Journal of Accounting, Finance and Business (IJAFB), Vol. 2 No. 6, pp. 110-122. 
Hattab, H.W. (2014), "Impact of entrepreneurship education on entrepreneurial intentions of university students in Egypt", The Journal of Entrepreneurship, Vol. 23 No. 1, pp. 1-18.

Hmieleski, K.M. and Corbett, A.C. (2006), "Proclivity for improvisation as a predictor of entrepreneurial intentions", Journal of Small Business Management, Vol. 44 No. 1, pp. 45-63.

Hockerts, K. (2017), "Determinants of social entrepreneurial intentions", Entrepreneurship Theory and Practice, Vol. 41 No. 1, pp. 105-130.

Hoffman, A.J., Badiane, K.K. and Haigh, N. (2012), "Hybrid organizations as agents of positive social change: bridging the for-profit and non-profit divide", Using a Positive Lens to Explore Social Change and Organizations, Routledge, pp. 152-174.

Kannampuzha, M. and Hockerts, K. (2019), "Organizational social entrepreneurship: scale development and validation”, Social Enterprise Journal, Vol. 15 No. 3, pp. 290-319.

Krueger, N.F., Jr, Reilly, M.D. and Carsrud, A.L. (2000), "Competing models of entrepreneurial intentions", Journal of Business Venturing, Vol. 15 Nos 5/6, pp. 411-432.

Langkamp Bolton, D. and Lane, M.D. (2012), "Individual entrepreneurial orientation: development of a measurement instrument", Education + Training, Vol. 54 Nos 2/3, pp. 219-233.

Liñán, F., Santos, F.J. and Fernández, J. (2011), "The influence of perceptions on potential entrepreneurs", International Entrepreneurship and Management Journal, Vol. 7 No. 3, p. 373.

Lortie, J. and Cox, K.C. (2018), "On the boundaries of social entrepreneurship: a review of relationships with related research domains", International Entrepreneurship and Management Journal, Vol. 14 No. 3, pp. 639-648.

Lorz, M. and Volery, T. (2011), The Impact of Entrepreneurship Education on Entrepreneurial Intention, University of St. Gallen.

Lumpkin, G.T. and Dess, G.G. (2001), "Linking two dimensions of entrepreneurial orientation to firm performance: the moderating role of environment and industry life cycle", Journal of Business Venturing, Vol. 16 No. 5, pp. 429-451.

Martín, C.T. and Cuervo-Arango, C. (2016), “A model for social entrepreneurship education”, Handbook of Research on Social Entrepreneurship and Solidarity Economics, IGI Global, pp. 174-191.

Miller, D. (1983), "The correlates of entrepreneurship in three types of firms", Management Science, Vol. 29 No. 7, pp. 770-791.

Ouedraogo, A. and Koffi, V. (2018), "Managing creativity and innovation in the cultural industries: evidence from three cultural organizations in Canada", Management Review: An International Journal, Vol. 13 No. 2, pp. 34-60.

Rauch, A. and Frese, M. (2007), "Let's put the person back into entrepreneurship research: a meta-analysis on the relationship between business owners' personality traits, business creation, and success”, European Journal of Work and Organizational Psychology, Vol. 16 No. 4, pp. 353-385.

Rauch, A. and Hulsink, W. (2015), "Putting entrepreneurship education where the intention to act lies: an investigation into the impact of entrepreneurship education on entrepreneurial behavior", Academy of Management Learning and Education, Vol. 14 No. 2, pp. 187-204.

Rauch, A., Wiklund, J., Lumpkin, G.T. and Frese, M. (2009), "Entrepreneurial orientation and business performance: an assessment of past research and suggestions for the future", Entrepreneurship Theory and Practice, Vol. 33 No. 3, pp.761-787.

Sahoo, S. and Panda, R.K. (2019), "Exploring entrepreneurial orientation and intentions among technical university students: role of contextual antecedents", Education + Training, Vol. 61 No. 6, pp. 718-736.

Satar, M.S. and Natasha, S. (2019), "Individual social entrepreneurship orientation: towards development of a measurement scale", Asia Pacific Journal of Innovation and Entrepreneurship, Vol. 13 No. 1, pp. 49-72. 
APJIE

15,1 Tran, A.T. and Von Korflesch, H. (2016), "A conceptual model of social entrepreneurial intention based
on the social cognitive career theory", Asia Pacific Journal of Innovation and Entrepreneurship, Vol. 10 No.1, pp. 17-38.

\section{Further reading}

Lorz, M. (2011), "The impact of entrepreneurship education on entrepreneurial intentions”, Unpublished doctorate thesis, University of St. Gallen.

\section{Corresponding author}

Muhammad Naveed can be contacted at: std_21682@iobm.edu.pk

For instructions on how to order reprints of this article, please visit our website: www.emeraldgrouppublishing.com/licensing/reprints.htm

Or contact us for further details: permissions@emeraldinsight.com 